\title{
REPRESENTATIVENESS OF THE MAMMALIAN COLLECTION OF THE ZOOLOGICAL MUSEUM OF LVIV UNIVERSITY
}

\author{
A. Zatushevskyy, I. Shydlovskyy, I. Tymkiv \\ Zoological Museum of Lviv Ivan Franko National University (Lviv) \\ Hrushevsky St. 4, Lviv, 79005 Ukraine \\ e-mail: andriyzatushevsky@gmail.com
}

Representativeness of the Mammalian Collection of the Zoological Museum of Lviv University. Zatushevskyy, A., Shydlovskyy, I., Tymkiv, I. - During collection inventorization of the Zoological museum of Lviv University we found that there are nearly 3800 exhibits belonging to 258 mammal species of the world's fauna. Most of the samples $(68 \%)$ represent the order of rodents (Rodentia). In systematic aspect, mammalian collections consist of representatives of 20 orders. The collections were founded by 264 persons, 28 of them made the main contribution. It is necessary to mention species listed in the Red Date Book of Ukraine: one species belongs to the category Extinct in the Wild (European bison), two - Extinct (Schreibers's longfingered bat, European ground squirrel), three - Data Deficient (bicolored shrew, lesser blind mole rat, gray dwarf hamster), five - to the category Not Evaluated (Nathusius' pipistrelle, European otter, short-tailed weasel, European polecat, common hamster). In addition, 9 species are rare, 12 belong to the category Endangered, and 18 are vulnerable in our country. Among representatives of mammals, in the museum's collections there are 229 species included into the Red List of the International Union for Conservation of Nature (Version 2015-4) belonging to six conservation status categories. The rarest ones among them are the species, which belong to the Critically Endangered category, such as the black-and-white ruffed lemur, diademed sifaka, Sunda pangolin, European mink, black rhinoceros, long-tailed chinchilla.

Key words: mammalian collections, representativeness, zoological museum, Lviv University.

Репрезентативність колекції ссавців Зоологічного музею Львівського університету. - Затушевський, А., Шидловський, І., Тимків, І. - Інвентаризацією колекцій Зоологічного музею Львівського Університету встановлено, що у фондах зберігаються понад 3800 зразків 258 видів ссавців фауни світу. Більша частина зразків, а саме, 68 \% — це представники ряду Гризуни (Rodentia). У систематичному плані, колекції ссавців складають представники 20 рядів. Фундаторами стали 264 особи, 3 яких 28 зробили основний внесок. Варто відзначити види, що занесені до Червоної книги України: один - зниклий у природі (зубр), два - зниклі (довгокрил звичайний, ховрах європейський) ці види мають такий статус згідно Червоної книги України: три - недостатньо відомі (білозубка велика, сліпак білозубий, хом'ячок сірий), п'ять - неоцінені (нетопир лісовий, видра звичайна, горностай, тхір лісовий, хом'як звичайний), 9 - рідкісні, 12 - зникаючі та 18 - вразливі. Представники теріофауни, занесені до Червоної книги МСОП, охоплюють шість категорій охоронного статусу 229 видів. Найрідкіснішими серед них $є$ ті, які належать до критично загрожених, зокрема: лемур варі, сифака діодемовий, панголін яванський, норка європейська, носоріг чорний, шиншила.

Ключові слова: колекції ссавців, репрезентативність, зоологічний музей, Львівський університет.

\section{Introduction}

In 2010, museum workers had made a big work on arragement and verification of species identification of exhibits, also on harmonization of their scientific names with the recognized mammalian taxonomy. As a result of this work, the "Catalogue of the Mammals collection of the Zoological Museum of Ivan Franko National University of Lviv" (Catalogue..., 2010) was published. After recent inventorization of the mammalian collection we found that there are ca. 3800 specimens in the museum funds representing 258 mammal species of the world. Most of the exhibits $(68 \%)$ are the representatives of the order of Rodents (Rodentia). 
The aim of this publication is to describe the mammalian collection stored in our museum and to show scientists previously unknown information on it. Also we want to emphasize that such collection is an important basis for investigation of species diversity and dynamics of changes of species distribution.

In the work we follow the taxonomy presented in the book "Mammals of the World" (2005), and in other sources such as the three-volume edition by V. Ye. Sokolov (1973, 1977, 1979), proceedings on mammalian taxonomy by I. V. Zagorodniuk (Zagorodniuk, 1998, 2001, 2008; Zagorodniuk, Godlevska, 2001 et al.) and publications by national and foreign mammalogists. Instead of scientific names recorded on original labels under the old nomenclature we used the modern scientific names, and the old ones we recorded as synonyms.

\section{Analysis of the collection}

In our opinion, the rarest objects in our collections are a bust of the black rhinoceros (Diceros bicornis), mounted platypuses (Ornithorhynchus anatinus), short-beaked echidna (Tachyglossus aculeatus), three-striped night monkey (Aotus trivirgatus), brown woolly monkey (Lagothrix lagotricha), western red colobus (Piliocolobus badius), Pousargues's mongoose (Dologale dybowskii), as well as all species of anteaters and sloths of the order Pilosa, and a number of other animals rare or absent in collections of other Ukrainian museums.

Mammalian collections of the museum are presented in general, according to the taxonomy given in the catalog, and shown in the table 1 . As we already noted, by the number of museum exhibits in the collection, the mostly represented is the order Rodentia, while the second place take the representatives of Soricomorpha $(15.5 \%)$, the third - Chiroptera, the fourth - Carnivora $(2.8 \%)$ and the fifth - representatives of Artiodactyla (1.4\%). By the type of museum exhibits, the collections of Mammals are represented in 5 categories, the most of them are study skins $-81.2 \%$, much less the skin-mounts and pelts $-7.0 \%$ and $10.2 \%$ respectively. Very small number of relatively new for museum types of exhibits - fluid-preserved specimens and mummies: $0.8 \%$ and $0.7 \%$ respectively (tab. 2 ).

Table 1. Representatives of different orders of mammals in the museum collection

Таблиця 1. Представленість різних рядів ссавців у колекції музею

\begin{tabular}{l|l|l|l|l|l}
\hline № & Order* & $\begin{array}{l}\text { Number } \\
\text { of specimens / species }\end{array}$ & № & Order & $\begin{array}{l}\text { Number } \\
\text { of specimens / species }\end{array}$ \\
\hline 1 & Monotremata & $3 / 2$ & 11 & Rodentia & $2591 / 76$ (74 are identified) \\
2 & Didelphimorphia & $3 / 6$ & 12 & Lagomorpha & $17 / 5$ \\
3 & Diprotodontia & $9 / 9(8$ are identified to species) & 13 & Erinaceomorpha & $20 / 4$ \\
4 & Afrosoricida & $1 / 1$ & 14 & Soricomorpha & $590 / 10$ \\
5 & Hyracoidae & $1 / 1$ & 15 & Chiroptera & $309 / 36 ?$ (32 are identified) \\
6 & Proboscidea & $1 / 1$ & 16 & Pholidota & $2 / 1$ \\
7 & Cingulata & $2 / 2$ & 17 & Carnivora & $107 / 43$ \\
8 & Pilosa & $7 / 5$ & 18 & Perissodactyla & $4 / 3$ \\
9 & Scandentia & $2 / 1$ & 19 & Artiodactyla & $52 / 31$ \\
10 & Primates & $36 / 25(23$ are identified) & 20 & Cetacea & $7 /$ min 2 (1is identified) \\
\hline
\end{tabular}

* Order of taxa according to MSW3 (Mammals..., 2005).

Table 2. Different types of specimens in the collection of the Zoological Museum Таблиця 2. Представленість різних типів зразків у колекції Зоологічного музею

\begin{tabular}{l|l|c}
\hline № & Type of exhibit & Number of specimens \\
\hline 1 & Skin-mounts & 268 \\
2 & Study skins & 3097 \\
3 & Pelts & 389 \\
4 & Fluid-preserved specimens & 31 \\
5 & Mummies & 28 \\
\hline
\end{tabular}


The geographic origin of specimens in the museum's collection covers almost all continents except Antarctica. Although from Antarctica we can include skulls of seals: Weddell seal (Leptonychotes weddellii), crabeater seal (Lobodon carcinophaga), Antarctic fur seal (Arctocephalus gazella), leopard seal (Hydrurga leptonyx) and South American sea lion (Otaria flavescens). Most of the exhibits originate from Ukraine (79\%). Much smaller number of specimens are from the Russian Federation $(9.6 \%)$ and Kazakhstan $(2.8 \%)$. Very few samples originate from other countries from $0.6 \%$ to single specimens (tab. 3 ).

The mammalian collection consists of samples amassed by 264 persons. The main contribution made 28 persons; they are listed in table 4. Besides, the table includes surnames of eminent naturalists, whose materials have little part in the mammalian collection, although they have special importance, because they complement the information about achievements and contribution of these researchers into zoological science.

During revision, except species identification of specimens, we also clarified their record localities and presented them according to the modern administrative divisions. These localities with exact geographic information not indicated on the original labels we noted in the catalog in brackets.

\section{History of enrichment of the mammalian collection}

The mammalian collection of the Zoological Museum of Lviv University was amassed during a long time from around the world. Specimens were brought to the museum by both specially organized expeditions and single researchers, who visited foreign countries; they were brought by ordinary people - mainly Lviv citizens, but during decades - also by citizens of other cities of the Austro-Hungarian Empire, Kingdom of Galicia-Volhynia, Polish-Lithuanian Commonwealth, West Ukrainian People's Republic, USSR and, of course, independent Ukraine (fig. 1).

Table 3. The geographical origin of specimens of the museum collections*

Таблиця 3. Географічне походження зразків з колекції музею

\begin{tabular}{|c|c|c|c|c|c|}
\hline № & Place of specimens' origin & $\begin{array}{c}\text { Number } \\
\text { of specimens }\end{array}$ & № & Place of specimens' origin & $\begin{array}{c}\text { Number } \\
\text { of specimens }\end{array}$ \\
\hline 1. & Australia & 1 & 20. & Republic of Madagascar & 2 \\
\hline 2. & Austria & 1 & 21. & Russia & 355 \\
\hline 3. & Belarus & 4 & 22. & USA & 1 \\
\hline 4. & Brazil & 5 & 23. & Tanzania & 13 \\
\hline 5. & Greece & 1 & 24. & Turkmenistan & 4 \\
\hline 6. & Georgia & 2 & 25 . & Ukraine & 2909 \\
\hline 7. & Venezuela & 1 & & Without clarification & \\
\hline 8. & Democratic Socialist Republic of Sri Lanka & 2 & & North Asia & 1 \\
\hline 9. & Kazakhstan & 102 & & Central Asia & 1 \\
\hline 10. & Kalimantan & 1 & & America & 1 \\
\hline 11. & Kenya & 23 & & North America & 1 \\
\hline 12. & Liberia & 5 & & Central America & 4 \\
\hline 13. & Moldova & 3 & & Africa & 6 \\
\hline 14. & Germany & 6 & & Europe & 1 \\
\hline 15. & Peru & 4 & & Scandinavian peninsula & 1 \\
\hline 16. & Romania & 1 & & unknown locality & 22 \\
\hline 17. & Republic of Angola & 1 & & without labels & 194 \\
\hline 18. & Republic of India & 1 & & & \\
\hline 19. & Republic of Indonesia & 4 & & Total & 3683 \\
\hline
\end{tabular}

* In addition, without extended information about place of origin, specimens were collected also in Altai, Africa, Lapland, Talas Alatau, South and Central America. From Wilhelm Schlüter Institute of Natural Sciences in Halle skin-mounts of Australian and South American mammals were imported. 
Table 4. Basic and eminent persons - founders of the mammalian collection of the Zoological Museum (ZMD) Таблиця 4. Основні та відомі особистості - фундатори колекції ссавців Зоологічного музею (ZMD)

\begin{tabular}{|c|c|c|c|c|c|c|c|c|}
\hline № & Collectioners & $\begin{array}{l}\text { Number } \\
\text { of spec. }\end{array}$ & № & Collectioners & $\begin{array}{l}\text { Number } \\
\text { of spec. }\end{array}$ & № & Collectioners & $\begin{array}{l}\text { Number } \\
\text { of spec. }\end{array}$ \\
\hline 1. & Polushyna, N. A. & 221 & 12. & Malchevska, K. P. & 55 & 23. & Makovska & 37 \\
\hline 2. & Yanushevych, M. & 217 & 13. & Mayevska & 55 & 24. & Postavska & 36 \\
\hline 3. & Senyk, A. F. & 140 & 14. & Lavriv, M. & 53 & 25 . & Wodzicki, Ye. & 33 \\
\hline 4. & Tkachynska, N. N. & 105 & 15. & Lomachenko & 52 & 26. & Voznyuk, M. & 33 \\
\hline 5. & Andrushko, L. V. & 97 & 16. & Maznova, T. D. & 48 & 27. & Zhuravchak, R. O. & 32 \\
\hline 6. & Kushniruk, V. & 93 & 17. & Vasylkiv & 44 & 28. & Kondratenko, O. & 30 \\
\hline 7. & Yemelianova, I. & 75 & 18. & Syerikova, O. M. & 44 & 29. & Dybowski, B. & 10 \\
\hline 8. & Bolekhivska, I. P. & 72 & 19. & Yatsun, T. I. & 44 & 30. & Kalinowski, J. & 4 \\
\hline 9. & Valenta, J. & 70 & 20. & Dobrovlianska, O. & 43 & 31. & Hirshler, J. & 4 \\
\hline 10. & Benedyuk, H. & 62 & 21. & Kovaliov & 41 & 32. & Sztolcman, [J.] & 1 \\
\hline 11. & Fedorenko, I. A. & 60 & 22. & Shostak Ye. & 39 & 33. & Nusbaum & 1 \\
\hline
\end{tabular}

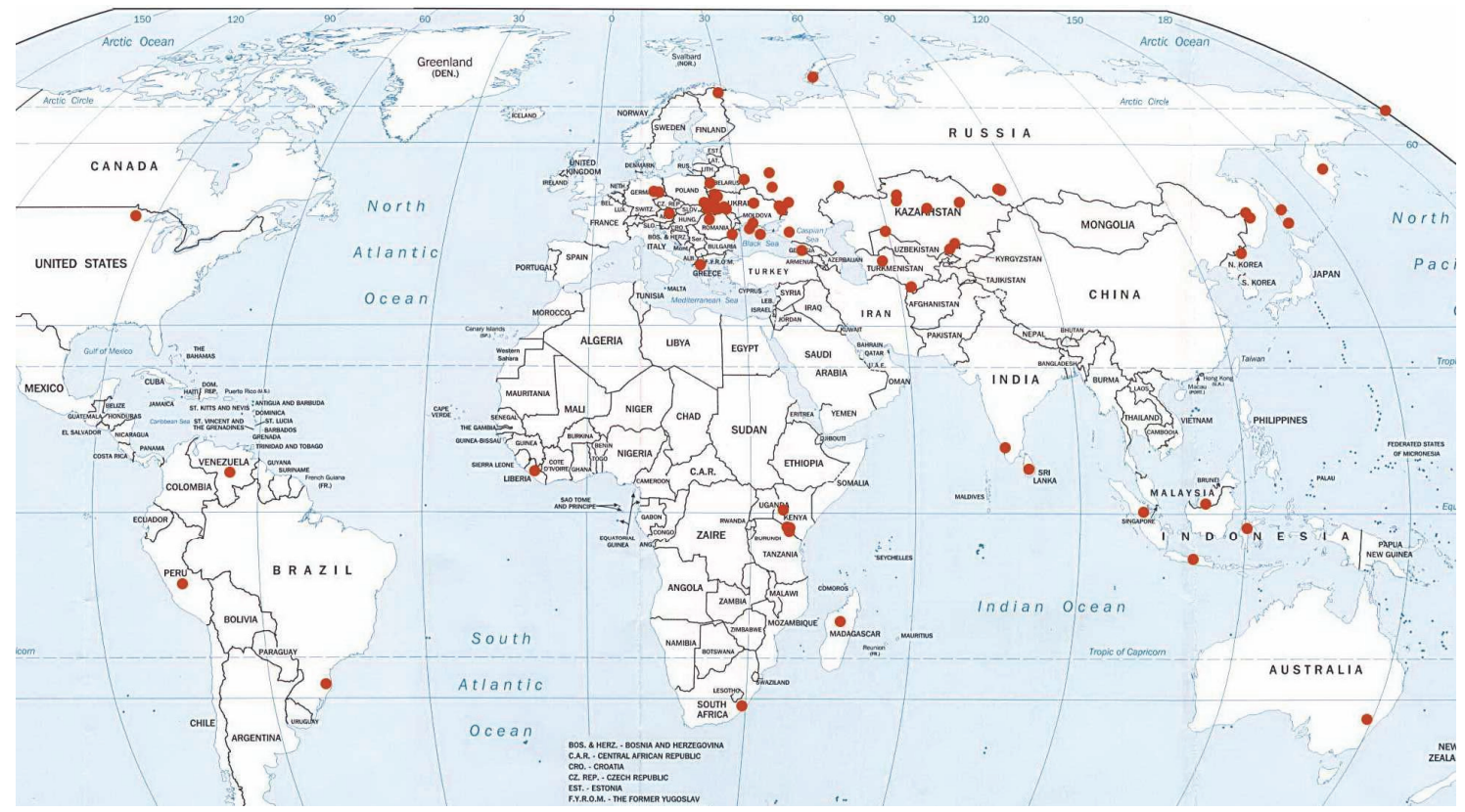

Fig. 1. The map of collection points of samples and separate zoological objects deposited in the Zoological Museum of Lviv Ivan Franko National University.

Рис. 1. Карта збору колекцій і окремих зоологічних об'єктів, які зберігаються в Зоологічному музеї Львівського національного університету імені Івана Франка.

The oldest exhibits of mammals the museum obtained in 1874. They were collected near Yarosłav city (now in Poland). During more than 230 years of history of the museum many exhibits had changed and now we can correctly enroll only those, which have original lables (Catalogue..., 2010; Shydlovskyy, 2012).

However, the museum's mammalian collection has continually updated, regardless of the course of history of our territories. An important contribution into enrichment of collections had made Benedykt Dybowski, the outstanding zoologist, naturalist, museum director, head of the Department of Zoology, and, later, dean of the Faculty of Philosophy. When he started to work in Lviv University, he passed his large collections from Lake Baikal, the Far East, Kamchatka and Galicia to the Cabinet of Natural History, which had also an agricultural and a medical collection. Due to his efforts, on 25 February 1885 the Cabinet of Natural History was reorganized into the 
Zoological Museum, which began to specialize in preserving of only zoological samples. Thanks to hard scientific work of B. Dybowski, his students also began to enrich museum collections. They had been travelling much, and some of them had left for domicile to another continent, for example, Jan Kalinowski who lived in Peru. Thanks to him museum collections were enriched by mammals from South America, which decorate the exposition (Zatushevskyy, Shydlovskyy, 2007, 2009; Shydlovskyy, Zatushevskyy, 2015).

Exhibits of Jerzy Wodzicki, who was a Lviv pilgrim, hunter and naturalist, occupy a prominent place in the Museum. In the early twentieth century he organized expeditions to Central Africa and to the mountains of Tien Shan.

In Africa (1909-1910), J. Wodzicki and his brother Alexander took part in a safari in a former German colony of East Africa (Deutsch-OstAfrica, DOA), which nowadays belongs to Tanzania (Tanganyika and area of Hot Springs valley ). Once they had got lost there and had to spend the night in the open air. Memories about that incident worried the travelers even a few years after returning from the safari. Despite this, according to the stories by J. Wodzicki, "there was warm at night, but oodles of mosquitoes and two lions, which were attracted by the fire and nice smell of dinner, had caused irritation". The inventive hunter managed to collect rich collections of busts and horns of different antelopes, a bust and a full body of juvenile giraffe (Giraffa camelopardalis) and a bust of black rhinoceros (Diceros bicornis).

Jerzy Wodzicki dissected all of the hunted animals at home during next two years, and processing of skins took all his free time. When the traveler arranged all of his collections, he began to dream about a new expedition to far territories, where would be difficult to hunt, but where life would be easy, free and without duties imposed by civilization. But he did not dare to a new expedition to the "black" continent - paradise for hunters. The previous trip was successful, but it was too expensive, because the climate was very difficult for white people, and nature was malevolent. Under such conditions a hunter often can easily become a prey. Alexander Wodzicki in 1911 dedicated to that travel a book "800 kilometers deep into Africa". After a while, J. Wodzicki began to think about a hunting trip to Canada, where he could find moose, reindeer and grizzly bear, the largest brown bear subspecies in the world. But the irrepressible hunter had been advised by friends from England to go to Central Asia, in particular to visit one of the largest mountain ranges that stretches north of the Himalayas - the mountains of Tien Shan.

In 1913, J. Wodzicki made his second expedition, at this time to the mountains of Tien Shan. He travelled there almost alone and took only a servant, hired a guide and a military assistant from Tashkent. Only in the end of the trip at the Chinese border and directly in China he gathered little more people to help him carry the trophies. The conditions of this trip were also difficult: "every day the half of our way passed through dangerous places, just one danger had passed, and the next one covered us immediately", the traveler wrote in his book "W górach niebiańskich (Tien-Szan)" (Wodzicki, 1938). Once J. Wodzicki with his assistants woke up covered by one meter of snow under a tree...

Among the trophies brought by the hunter from Asia, there were 40 pairs of horns, and they hardly settled on a cart.

After J. Wodzicki's death on 9 February 1952, his collections were passed to our museum by his wife Maria for permanent storage.

Another valuable mammalian collection was the one collected in Liberia during Professor Jan Hirshler's expedition, who travelled to Africa with his wife and spent there two years (1936-1937). However, this expedition was mainly focused on collecting of reptiles and insects for the Museum, and from mammals he brought only bats (Hirschler, 1938).

World War II damaged the museum's educational work. During German occupation all museum funds were dumped in the hall of birds in one big heap and stayed there until the end of war. Immediately after resumption of the University, the museum began to arrange its collections and organize expeditions. 
The first collections after war were mainly individual and made by M. T. Yanushevych (Transcarpathian region, 1946-1949), Antkiv and Brytskyy (Lviv, 1948), Bytchko (Transcarpathian region, 1948), D. V. Vladyshevskyy (Transcarpathian region, 1949), Maltchenko, Pospielov (Lviv, 1949), Ya. M. Vasylkiv (Lviv region, 1950), Lavrynenko, Masnyy, Pokalo (Transcarpathian region, 1950).

In the 1960s, Josef Valenta and Galyna Benediuk were studying the rodent fauna of the Transcarpathian region and passed their scientific collections to the museum. Their big collections created during 1952-1955 are still preserved in the museum. Volodymyr Kushniruk also amassed a big collection from the Carpathians and Transcarpathian region during 1952-1957.

Museum collections were enriched by specimens from Antarctica brought by the whale-hunting floating factory "Slava" in 1956. Mainly that were osteological materials, but also, besides bones, there were embryos of different baleen whales. In addition, baleen of the common minke whale (Balaenoptera acutorostrata) and other whale species were also collected.

From 1957, the museum's collections were enriched by T. M. Yatsun, who collected materials in the Black Sea Biosphere Reserve, and Serikova, who worked in Crimea (Gaspra).

During 1958-1959, the geographical coverage of the museum's collections increased thanks to expedition to the Caucasus, in particular to the Caucasus Nature Reserve, where near the Kish River Ye. H. Shostak gathered a large collection of rodents. Z. I. Pavliv and V. V. Veselovskyy continued to amass materials from Crimea and the Carpathians. M. Lavriv and I. Yavorskyy went to steppes of the Kustanai region, Kazakhstan in 1962.

In 1966, there was an expedition to the Western Caucasus, to the Caucasus Nature Reserve (vicinities of Huzerypl). This territory was visited by Kovaliov, Lomatchenko and Ilkiv, who gathered a significant collection of rodents on subalpine meadows. I. Yemelianova brought a large collection of rodents from the Black Sea Nature Reserve in 1967. She was doing her pre-degree practice on the theme "Zoogeography of mammals of the Black Sea Nature Reserve" under guiding of N. A. Polushyna. At that time relative and absolute censuses of small mammals and ungulates were conducted, thanks to which a huge amount of raptor pellets and carnivore excrements were collected and processed.

Researching and collecting of scientific materials in the territory of Talas Alatau were made by Romaniuk in 1972. M. N. Vozniuk (21.09.1929-05.11.2003) being the museum's director organized an expedition to Kazakhstan (Arica, Karaganda region) along with a geobotanical expedition, where she gathered a large collection for the museum. Later M. N. Vozniuk also collected materials in the western regions of Ukraine.

Great contribution to the museum collections was made by the Laboratory of Geobotanical Research of the Biological faculty of Ivan Franko National University of Lviv leaded by V. M. Turkevytch. He organized expeditions to Kazakhstan, Altai and Kurgan Khanty-Mansiysk during 19741997 and brought interesting specimens from those locations. Volodymyr Turkevytch passed to the museum his personal collection of steppe saiga horns including the winners of the Exhibition of Achievements of National Economy (EANE) in Moscow, which took place on 11 April 1980. The gold-winning horns of saiga acquired in Kazakhstan were estimated of 81.4 points, two silver medals were awarded to saiga horns acquired in Kazakhstan in 1977 and 1979 and estimated of 70.5 and 74.8 points, respectively. The bronze medal was awarded to a saiga horn acquired in Kazakhstan in 1977 and estimated of 69.8 points. V. M. Turkevytch was awarded the gold and bronze medals for obtaining valuable trophies on the III Republican Exhibition of Trophies of the Ukrainian Society of Hunters and Fishermen in Kiev on 8 September 1988.

Collections of docent N. A. Polushyna, who spent all her life studying mammals in Lviv, in the Carpathians and Transcarpathia region, are of high importance and value.

Among new acquisitions, special attention deserve specimens collected by O. V. Kondratenko (1975-2004), a terriologist, docent of Luhansk Taras Shevchenko National University during 19972004 in the Luhansk Natural Reserve and its vicinities. 
Table 5. Different mammal species from the museum's collections and their status in the Red List of the International Union for Conservation of Nature (Version 2015-4)

Таблиця 5. Представленість різних видів ссавців, з колекції музею, та їхній статус у Міжнародній Червоній книзі (Version 2015-4)

\begin{tabular}{|c|c|c|c|c|c|}
\hline Status (Categories) & Total & Stable & $\begin{array}{c}\text { Un- } \\
\text { known }\end{array}$ & $\begin{array}{l}\text { Decre- } \\
\text { asing }\end{array}$ & $\begin{array}{l}\text { Incre- } \\
\text { asing }\end{array}$ \\
\hline $\begin{array}{l}\text { CR (Critically endangered) - extremely high risk of extinction in } \\
\text { the wild }\end{array}$ & 6 & - & - & 5 & 1 \\
\hline EN (Endangered) — high risk of extinction in the wild & 10 & - & - & 10 & - \\
\hline VU (Vulnerable) - high risk of endangerment in the wild & 17 & - & 2 & 13 & 2 \\
\hline $\begin{array}{l}\text { NT (Near threatened) - likely to become endangered in the near } \\
\text { future }\end{array}$ & 16 & - & 1 & 15 & - \\
\hline $\begin{array}{l}\text { LC (Least concern) - the lowest risk. Does not qualify for a more } \\
\text { at-risk category }\end{array}$ & 178 & 81 & 50 & 36 & 11 \\
\hline $\begin{array}{l}\text { DD (Data deficient) - not enough data to make an assessment of } \\
\text { its risk of extinction }\end{array}$ & 3 & - & 2 & 1 & - \\
\hline
\end{tabular}

Analyzing samples of rare species in the museum's collections, species listed in the Red Date Book of Ukraine (Red Data Book..., 2009) should be also noted. In particular, representatives of all seven conservation status categories are present in the museum's collections. One species belongs to the category Extinct in the Wild (European bison Bison bonasus), two - to the category Extinct (Schreibers's long-fingered bat Miniopterus schreibersii, European ground squirrel Spermophilus citellus), three - Data Deficient (bicolored shrew Crocidura leucodon, lesser blind mole rat Nannospalax leucodon, gray dwarf hamster Cricetulus migratorius), five - to the category Not Evaluated (Nathusius's pipistrelle Pipistrellus nathusii, European otter Lutra lutra, short-tailed weasel Mustela erminea, European polecat M. putorius, common hamster Cricetus cricetus). In addition, nine species are rare in Ukraine, 12 belong to the category Endangered, and 18 considered in status Vulnerable.

Among mammal species represented in the mammalian collection of the museum, there are 229 included into the Red List of the International Union for Conservation of Nature (The IUCN Red List..., Version 2015-4) belonging to six conservation status categories.

Among mammal species represented in the museum's collection, the rarest ones belong to the category of Critically Endangered species, such as the black-and-white ruffed lemur Varecia variegata, diademed sifaka Propithecus diadema, Sunda pangolin Manis javanica, European mink Mustela lutreola, black rhinoceros Diceros bicornis and the long-tailed chinchilla Chinchilla lanigera (tab. 5).

The museum's collections are continuing to grow and expand nowadays. It occurs mainly due to scientific activity of the employees of the museum and the Department of Zoology of Ivan Franko National University of Lviv, and also because of the work of volunteers, students, PhD students, naturalists, etc., who bring to the museum dead animals. Except scientists from Lviv, museum collections are being enriched by scientists from other cities.

\section{Acknowledgements}

We wish to thank Z. Barkasi for proofreading and linguistic corrections of the manuscript.

\section{References}

Загороднюк, I. B. Вищі таксони ссавців у сучасній фауні України: склад, номенклатура та видове багатство // Доповіді НАН України. — 1998. — № 4. - Р. 180-186.

[Zagorodniuk, I. V. Higher taxa of mammals in the modern fauna of Ukraine: composition, nomenclature and species richness // Reports of the National Academy of Sciences of Ukraine. - 1998. - No. 4. - P. 180-186. (in Ukr.)]

Загороднюк, I. В. Роди звірів східноєвропейської фауни та їх українські назви // Вісник Національного науково-природничого музею НАН України. 2001. — Том 1. - С. 113-131. 
[Zagorodniuk, I. V. Genera of mammals of the East-European fauna and their Ukrainian names // Proceedings of the National Museum of Natural History. - 2001. - Vol. 1. - P. 113-131. (in Ukr.)]

Загороднюк, I., Годлевська, Л. Кажани в колекціях зоологічних музеїв України: Огляд і фенологічний аналіз даних // Міграційний статус кажанів в Україні. - Київ, 2001. - С. 122-156. — (Novitates Theriologicae; Pars 6).

[Zagorodniuk, I., Godlevska, L. Bats in the collections of zoological museums of Ukraine: phenological review of data // Migratory Status of the Bats in Ukraine. - Kyiv, 2001. - P. 122-156. — (Novitates Theriologicae; Pars 6). (in Ukr.)]

Загороднюк, I. Наукові назви рядів ссавців: від описових до уніфікованих // Вісник Львівського університету. Серія Біологічна. - 2008. - Вип. 48. - С. 33-43.

[Zagorodniuk, I. Scientific names of mammalian orders: from descriptive to uniform // Visnyk of Lviv University, Biology series. - 2008. — Iss. 48. — P. 33-43. (in Ukr.)]

Затушевський, A. T., Шидловський, I. В. Історія комплектування колекції ссавців Зоологічного музею Львівського національного університету ім. Івана Франка // Проблеми і перспективи розвитку музеїв вищих навчальних закладів України (Київ, 23-24 листопада 2007 р.). - Київ, 2007. — С. 20-21.

[Zatushevskyy, A. T., Shydlovskyy, I. V. History of completing of mammals collection of the Zoological Museum of Ivan Franko National University of Lviv // Problems and prospects of museums of educational institutions of Ukraine (Kyiv, November, 23-24, 2007). - Kyiv, 2007. - P. 20-21. (in Ukr.)]

Затушевський, А. Т., Шидловський, І. В. Колекція ссавців зоологічного музею Львівського національного університету імені Івана Франка // Природнича музеологія: теорія та практика : Мат-ли Всеукраїнської науково-практичної конференції (17-18 вересня 2009 р., м. Кам’янець-Подільський). — Львів, Кам’янець-Подільський, 2009. - С. 121-122.

[Zatushevskyy, A. T., Shydlovskyy, I. V. Mammals collection of the Zoological Museum of Ivan Franko National University of Lviv // Natural museology: theory and practice / Materials of Ukrainian Scientific and Practical Conference (September, 1718, 2009, Kamianets-Podilskyi). — Lviv, Kamianets-Podilskyi, 2009. — P. 121-122. (in Ukr.)]

Каталог колекцій ссавців Зоологічного музею Львівського національного університету імені Івана Франка / Уклад.: Затушевський А. Т., Шидловський І. В., Закала О. С. та ін. - Львів : Видавничий центр ЛНУ імені Івана Франка, 2010. - 442 с.

[Catalogue of the mammals collection of the Zoological Museum of Ivan Franko National University of Lviv / Zatushevskyy, A. T., Shydlovskyy, I. V., Zakala, O. S. et al. - Lviv : Publishing Center of Ivan Franko National University of Lviv, 2010. - 442 p. (in Ukr.)]

Соколов, В. Е. Систематика млекопитающих. Отряды: зайцеобразных, грызунов. - Москва : Высшая школа, 1977. $-494 \mathrm{c}$

[Sokolov, V. E. Taxonomy of Mammals. Orders Lagomorpha and Rodentia. — Moscow : High School, 1977. — 494 p. (in Rus.)]

Соколов, B. E. Систематика млекопитающих. Отряды: китообразных, хищных, ластоногих, хоботных, даманов, сирен, парнокопытных, мозоленогих, непарнокопытных. - Москва : Высшая школа, 1979. — $528 \mathrm{c}$.

[Sokolov, V. E. Taxonomy of Mammals. Orders Cetacea, Carnivora, Pinnipedia, Proboscidea, Hyracoidea, Sirenia, Artiodactyla, Perissodactyla. - Moscow : High School, 1979. - 528 p. (in Rus.)]

Соколов, В. Е. Систематика млекопитающих. Отряды: однопроходных, сумчатых, насекомоядных, шерстокрылов, рукокрылых, приматов, неполнозубых, ящеров. - Москва : Высшая школа, 1973. — 432 с.

[Sokolov, V. E. Taxonomy of Mammals. Orders Monotremata, Marsupialia, Insectivora, Dermoptera, Chiroptera, Primates, Xenarthra, Pholidota. — Moscow : High School, 1973. — 432 p. (in Rus.)]

Червона книга України. Тваринний світ. / За ред. І. А. Акімова. — Київ : Глобалконсалтинг, 2009. — 624 с.

[Akimov, I. A. (ed.). Red Data Book of Ukraine. Animals. — Kyiv : Globalconsalting, 2009. — 624 p. (in Ukr.)]

Шидловський, I. Історія музейної справи та зоологічних музеїв університетів України / Ред. Й. Царик. Львів : ЛНУ ім. І. Франка, 2012. - 112 с.

[Shydlovskyy, I. V. History of Museum Work and Zoological Museums of Universities of Ukraine / Ed. by Tsaryk, J. — Lviv : Ivan Franko National University of Lviv, 2012. - 112 p. (in Ukr.)]

Hirschler, J. Ze Lwowa do Liberii. Wspomnienia z Afryki tropikalnej. — Lwów, Warszawa : Książnica Atlas, 1938. - $240 \mathrm{~s}$.

Mammal Species of the World: a Taxonomic and Geographic Reference. Third edition. — The Johns Hopkins University Press, 2005. — 2142 p. — https://goo.gl/uRvrbi

Shydlovskyy, I., Zatushevskyy, A. Private collections in the Zoological museum of Lviv University // Natural History Museums: role in education and science: Proceedings of the IV International Conference / National Museum of Natural History of Ukraine; Ed. by I. Zagorodniuk. - Kyiv, 2015. — Vol. 2. - P. 76-78.

Wodzicki J. W górach niebiańskich (Tien-Szan)". Wspomnienia z polowań na kozioroźce i dzikie barany. — Lwow, 1938. - $333 \mathrm{~s}$.

The IUCN Red List of Threatened Species. Version 2015-4. — www.iucnredlist.org. Downloaded 11 April, 2016. 